\title{
РИТУАЛОТ НА ЖРТВУВАЊЕ И ЕКОНОМИЈАТА НА НАСИЛСТВОТО (низ примери од македонските народни легенди и опусот на Марко Цепенков)
}

\author{
Катица К̈улавкова \\ Македонска академија на науките и уметностите \\ kkulavkova@gmail.com
}

\begin{abstract}
Митската и историската меморија се двете лица на истата стварност. Народното предание потсетува дека зад големите епски херои и митски подвизи стојат големи трагедии. Зад големите дела на културата се кријат потресни човечки и национални приказни. Колективната меморија на Македонците е сензибилна, па умее не само да ги идеализира туку и да ги демистифицира историските личности и настани. Во македонската народна традиција се зачувани бројни легенди, приказни и песни во коишто се евоцира мотивот на жртвување, како во неговата архаична ритуална форма (зазидување жива жена во темелите на мостовите) така и во неговите феудални форми на социјална и културна политика. Притоа, вниманието ќе биде свртено кон преданијата за Крале Марко (1335-1395) и за Марковите кули запишани од Марко Цепенков (1829-1920). Во овој текст се прави основна класификација на насилството (нужно наспроти ненужно насилство).
\end{abstract}

Клучни зборови: ритуал, жртвен јарец, втемелувачко насилство, економија на насилството, Марко Цепенков 


\title{
THE RITUAL OF SACRIFICE AND THE ECONOMY OF VIOLENCE (Through examples from Macedonian folk legends and the work of Marko Cepenkov)
}

\author{
Katica Kulavkova \\ Macedonian Academy of Sciences and Arts \\ kkulavkova@gmail.com
}

Mythic and historical memory are two sides of the same reality. Popular legends remind us that there are great tragedies behind great epic heroes and mythic feats. Hidden behind the great works of culture lie shocking human and national stories. The collective memory of the Macedonians is sensitive and, apart from the ability to idealize, it can also demystify historical figures and accounts. Macedonian popular tradition keeps numerous legends, stories and poems which evoke the motif of sacrifice, both in its archaic ritual form (burying a live woman in the foundations of bridges) and in its feudal forms of social and cultural politics. The focus of this paper will be on the legends of King Marko (1335-1395) and Marko's Towers written by Marko Cepenkov (1829-1920). This text will make a basic classification of violence (necessary versus unnecessary violence).

Keywords: ritual of sacrifice, bouc émissaire, founding violence, economy of violence, Marko Cepenkov 


\section{1 Жртвен јарец}

Според теоријата на Рене Жирар, во темелите на секоја култура е положена некоја човечка жртва. Станува збор за еден „примитивен“ ритуал, кој ја вклучува фигурата на жртвениот јарец (“bouc émissaire”) (Girard 2002). Со текот на времето жртвениот јарец е заменет со некоја симболична материјална или животинска жртва (и во буквална смисла на зборот ,jаре“). На македонски јазик е популарна деминутивната форма „жртвено јаре“, која евоцира или некој стар образец на жртвување дете, или изразува извесна жал и симпатија спрема жртвата или можеби дискретно ја оправдува традицијата на жртвување.

Жртвениот јарец на помирувањето и каењето, всушност, е слика на идеалната жртва, која страда поради туѓите гревови и така ги откупува. Се чини дека гревовите не можат да бидат укинати ни простени самите по себе, но можат да бидат пренесени од еден субјект врз друг. Има нешто мистично, а не само симболично во феноменологијата на гревот. Жртвениот јарец е неопходен за да се пренесат врз него туѓите гревови, затоа што токму тој пренос на гревовите врз другиот е услов за да се дојде до прочистување од гревовите, што e, пак, услов за да се изгради нешто вечно и нешто од општ и виш интерес.

\section{1 Ритуал на жртвување}

Вечноста не е ни наивна ни невина. Таа знае да биде изговор за нови трагедии и „свети насилства“ (“victime émissaire”) над луѓето и над културните добра, за манипулацијата со светите нешта (животот, слободата и основните права на човекот) и за легитимирање на ритуалите на жртвување. Чинот на жртвување, стварно или симболично, значи, е услов за да се востанови нов ред на нештата, нова култура. Ритуалот на жртвување во име на некоја виша цел или за „општо добро“ вклучува елементи на таканареченото „втемелувачко насилство" ("la violence fondatrice" / "the founding violence") (Girard 2002). Toj е една од најдолготрајните традиции на човечката цивилизација, па затоа претставува конститутивна функција на секоја (нова) култура. Ритуалот „го репродуцира точниот ред на првобитните настани“ (Girard 2002: 472) и упатува на универзалноста на миметичкото начело. „Кризата на ритуалот е предуслов за да се роди трагедијата“" (ibid., 86).

Новите историски констелации само го актуализираат и го осовременуваат чинот на насилно жртвување, но не го укинуваат. Напротив, новите епохи познаваат и брутални облици на масовно жртвување на цели популации (врз расна, етничка и религиска основа) во име на вулгарно прагматични цели (од расизам до империјализам). Разликата е во тоа што современата цивилизација свесно избегнува да создава фигури на жртви, затоа што жртвата лесно се претвора во херој и се дивинизира. Од тие причини, денес жртвата порадо се 
сатанизира одошто се дивинизира. И најневината жртва, кога е сатанизирана, не се доживува како жртва, а насилството над неа се прима како оправдано.

\section{2 Нужно (втемелувачко) насилство}

Остварувањето на големите зафати, кои го носат предзнакот на „општо добро“, подразбира извесно жртвување (и саможртвување), а жртвувањето, пак, доза на „нужно насилство“ (нужно зло кое може да се смета за варијанта на т.н. втемелувачко насилство). Во такви услови, насилството е неизбежно, односно конститутивно или системско. Нужното насилство, како конститутивно, се изведува под закрила на некој ритуал, било тој да е експлицитен или имплицитен. Ако ја прифатиме тезата дека востановувањето нови културни и цивилизациски парадигми и погледи на свет, нови конфесии и етички кодекси, како и нови режими, вклучуваат извесна доза на насилство, тогаш би требало нужното насилство да го прифатиме како законито, а со тоа и како предвидливо. Предвидливото насилство може да се сведе на поднослив минимум или да се трансформира на таков начин што жртвите/загубите ќе бидат надоместливи. Таквиот пристап применува стратегии на економизација на насилството. Идејата дека доброто не го исклучува злото/насилството е универзална мудрост изведена врз основа на универзално искуство. Парадоксот, значи, е основа на големите мудрости. Таков е случајот и со архетипот на зло-доброто, кој, како универзално искуство, е подложен на разни историски актуализации.

И универзалната традиција на жртвување во име на некое општо добро има разни локални варијанти на насилство, најчесто насочено кон Другиот. За да се смени системот (на подобро) или за да се изгради некое здание од општ интерес, се нанесуваат неправди над луѓето од различен вид. Предмет на жртвување се ниските социјални слоеви на населението (евтината работна „рака“), робовите, туѓинците. Субјектот кој го иницира жртвувањето е Владетелот (монарх, император, феудалец, претседател или премиер на држава, глобален фактор во сферата на т.н. дискурс на моќта).

Методот со чијашто помош се спроведува жртвувањето е маскиран во култни флоскули: за добро на народот, за заштита на државата, во име на подобра иднина, во име на Бога. Хипокризијата е измислена за да се прикрие бруталноста на жртвувањето. Постојат идеали и дела чие остварување вклучува ризик и жртва. Всушност, жртвата е другото име на ризикот. Последиците од ризикот се делумно предвидливи и повратни, а делумно непредвидливи и неповратни. Поради тоа, секое одредување на границите на оправданото и нужно насилство од неоправданото и ненужното е морално деликатна задача.

\section{3 Ненужно насилство}

Додека зад нужнойо насилстиво постои некоја виша цел, која ги оправдува средствата/жртвите, а жртвувањето претставува средство (начин, метод) за да 
се постигне одредена виша цел за општо добро на сите, за т.н. ненужно насилсииво вишата цел, односно општото добро, е само хипокритичен изговор за остварување на некој лукративен и прагматичен интерес.

Улогата на ритуалот се состои во тоа да го прикаже насилството како нужно жртвување, односно жртвувањето како нужно насилсӣво, било да е единично (митско) или масовно (историско). Но, постои и еден друг тип насилство, што ќе го идентификуваме како ненужно насилсӣво. Ненужното насилство подразбира не само прекумерност на насилството туку и насилсйво зараяи насилсйво, самоцелно насилство без никакво покритие, поради што ќе го идентификуваме како апсолутно насилство.

Една бегла споредба меѓу неколкуте специфични видови насилство (ритуално, нужно, ненужно, апсолутно насилство) покажува дека едните облици на насилно жртвување имаат некакво покритие во некое општо добро, додека другите немаат никакво покритие. Првите имаат свој логос, колку овој и да е мрачен, поради што се достапни за толкување, објаснување, а некогаш и за оправдување. Вторите, оние што спаѓаат во категоријата апсолутно

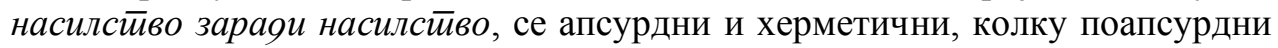
толку похерметични.

\section{4 Апсолутно насилство}

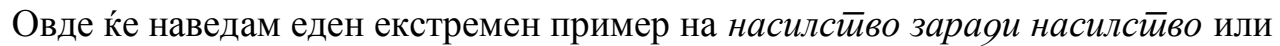
на т.н. апсолутно насилство (една негова варијанта е садизмот). Станува збор

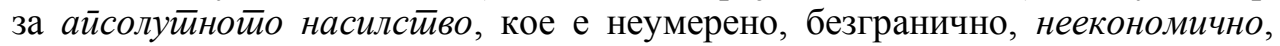
чисто зло, кое нема виша цел и кое си е доволно на самото себеси, кое е цел за себе, па дури е последица/алатка на нижи цели (геноцид, Шоа, културоцид, верски и политички фанатизам, садизам). Таков е (европскиот) случај опишан во романот Sophie's Choice (Избороӣ на Coфија) на американскиот писател Вилијам Стајрон (1979), според којшто е сниман истоимениот филм на Алан Пакула (1982). Приказната е заснована врз вистински случај, според којшто, во Аушвиц, еден нациофицер ѝ наредува на Софија, католик од Полска, мајка на две деца да го одбере, безусловно, брзопотезно, едното (дете) што ќе му го отстапи на логорот. Софија е принудена да избира кое дете ќе го жртвува, оти во спротивно и двете ќе ѝ бидат одземени. Жртвувањето на едното дете му доаѓ како иронична, безумна иронија на слободата на избор меѓу две зла. Кое е помалото зло? Ова е парадигматичен пример на наметната слобода на избор, која уште создава привид дека несреќата можела да биде и поголема. Нема утеха оти нема покритие за стореното зло. Во извесна смисла, и лицето што го врши изборот е принудно ставено во ситуација да ја сподели одговорноста со злосторникот. Таквиот тип „избор“ е манипулативен и има цел да ја пренесе одговорноста од вршителот на злото врз другиот, субјектот што го трпи злото/ насилството. Со овој пример се укажува и на феноменот на „насилственоста“ како латентно антрополошко обележје на човештвото (К'улавкова 2009). 


\section{5 Ритуално насилство}

Архаичните примери сведочат за бројни пагански ритуали на жртвување живи и невини луѓе за општо добро. Тоа општо добро (т.н. виша цел) се препознавало во: идејата за поврзување два света преку поврзување два брега на реката (подигање мост); потребата од градење тврдини и кули за спас на народот од војна и терор; подигање манастири и цркви во слава на Бога. При ритуалното жртвување, насилството има сакрална димензија, па се прифаќа како кармичко/неизбежно и традиционално, така што е маргинализирана неговата бруталност. И владетелите и народот му се покорувале на традиционалниот ритуал.

Народното предание има суптилна меморија, па прикажува не само јасни, недвосмислени туку и некои двосмислени случаи и ситуации на жртвување. Таквите двосмислени ситуации го поставуваат деликатното прашање - дали навистина за остварување на некое „општо добро“ се неопходни (нужни) жртви, па дури и брутални? Во македонското народно предание има примери во коишто сеќавањето не е прочистено од непожелни етички елементи и укажува на проблематичноста на самиот чин на жртвување, било тоа да се одвива под претекст на ритуал или за општо добро. И едните и другите примери го мистифицираат насилството со помош на ритуалот, неретко преобразен во народен обичај, паганска традиција, суеверие...

\section{2 Ритуалното жртвување во македонската колективна меморија}

Во македонското народно предание зачувани се повеќе примери за ритуално и насилно жртвување. Еден од нив е поврзан со подигањето мостови. Жива е легендата, на пример, за подигањето на Радиниот мост во Кратово. Тоа е локализирана историска варијанта (мостот е изграден 1833 година на Манцева Река) на архетипот на заsидување жива жена доилка во темелите на мостот, со цел мостот да биде вечен. „Што се мора не е тешко“, вели една поговорка. Тоа е тој фаталистички и религиски контекст, кој му дава света димензија на насилството (виша волја). Во случајов се работи за девет браќа sидари што го граделе мостот, и за жената на најмладиот брат, Рада.

Иронијата е во тоа што само навидум е сѐ оставено на случајот. За волја на вистината, сите браќа ги предупредиле сопругите да не одат следниот ден да им носат ручек на мајсторите, единствено најмладиот брат чесно го почитувал договорот и не ѝ кажал на својата сопруга што ќе ѝ се случи ако им однесе ручек. Приказната е драматизирана со тоа што младата мајка е доилка, па ги моли мајсторите да ѝ ја остават едната дојка незамидана за да може да го дои своето дете. Митската слика на жена „жива заsидана“ побудува и ирационален страв од заsидување на сенката на човекот, па затоа луѓето бегале подалеку од sидовите. Во ова предание Божјата волја е трансферирана на хазарден начин. „Играта на среќа“" се трансформира во „игра на несреќа“. Насилното жртвување е извршено под форма на традиционално мистично паганско верување, кое ги 
ослободува актерите од нивната вина. Ритуалот има, значи, катарсична и морална улога - да го оправда насилството.

Ова предание се сретнува кај повеќето јужнословенски и балкански народи. Популарна е српската варијанта, која се однесува на зидањето на тврдината на Скадар, која раскажува за тројца браќа мидари, додека сите други елементи на раскажувачката ситуација се исти. ${ }^{1}$ Ова предание, во верзија што се однесува на мостот на реката Бојана во Скадар, е преработено од Маргерит Јурсенар (1903-1989) во расказот Млекойо на смрӣ̄̄a (Le Lait de la mort), објавен во нејзината збирка Ориенйални новели (1938). ${ }^{2}$

Но, има и едно предание запишано од Марко Цепенков, објавено под број

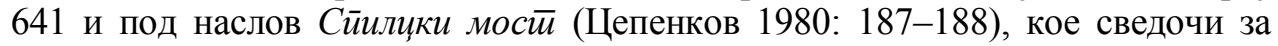
новата култура на супституција на ритуалот на жртвување, па наместо живи луѓe или животни (курбан), се жртвуваат материјални добра, односно пари. Спилцкиот мост, подигнат над реката Дрим, во близина на Дебар (Македонија), опстанал дури откако еден мајстор наложил во реката под мостот со лопата да се фрлат пари. Инаку, и денес остатоци од паганизмот се трансферирани во бројни религиски/верски и парарелигиски ритуали на жртвување.

\section{1 Профанизација на ритуалот на насилството}

Едно друго предание го привлекува посебно нашето внимание. Тоа предание се однесува на легендарниот народен јунак Крале Марко, синот на кралот Волкашин (од фамилијата Мрњавчевиќ). Марко владеел од 1371 до 1395 година, за време на освојувањето на Балканот од страна на Османлиите, односно за време на доминацијата на средновековната српска држава (царство) во Македонија. Станува збор за легендата Маркои кули и Кукул, запишана под број 607 од Марко Цепенко (Пенушлиски т. 7, 1980: 136-138), која не става акцент врз архаичниот ритуал, туку врз социјалниот аспект на жртвувањето, при што жртвите на социјалното насилство не се ни сатанизирани ни дивинизирани, туку маргинализирани и злоупотребени во полза на општото добро. Тоа општо добро е препознаено како sидање на Марковите кули над градот Прилеп, со цел да се спречи пробивот на Османлиите и да го спаси народот од поголемото зло, но воедно и самиот себеси да се спаси. ${ }^{3}$

Според оваа легенда, подигањето на кулите над Варош/Прилеп е изведено „со голем зулум“, кој го сторил легендарниот народен херој Крале Марко

\footnotetext{
1 Во една епска песна од преткосовскиот циклус српски народни песни (според Вук Стефановиќ Караџиќ), се работи за три историски личности, за тројцата браќа Мрњавчевиќ (Волкашин, Углеша и Гојко), кои ја граделе тврдината на градот Скадар, на реката Бојана.

${ }^{2}$ Расказот на македонски е објавен под наслов Sugaњет̄о на Скаgар во антологијата Црни овии (2008).

3 Според едно друго предание за Крале Марко, тој градел Маркови кули и над градот Штип (познати како Исарот), во исто време кога неговата сестра се мачела да подигне мост над реката Брегалница. Сестрата му префрла на братот дека прави нешто небитно во споредба со важноста на мостот кој би бил од корист за сите жители во околината и пошироко (Маркови кули во

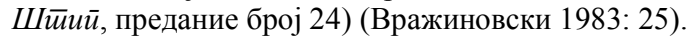


(зулум е турцизам што означува неправда, насилство, зло, суровост): „За тие изурнати денешни кули си прикажуа од стари оти со голем зулум сей йраени г̇oa og Марка Кралейа“ (Цепенков 1980 т. 7: 136). Легендата Маркои кули и Кукул отвора серија прашања: Какво е насилството што го извршил Крале Марко? Посредно или непосредно? Кои се жртвите на оваа неправда? Дали фанатичната градба на Марковите кули (Калето) во име на заштита на народот е валидно покритие за насилството извршено над децата, колку и да е тоа иняи-

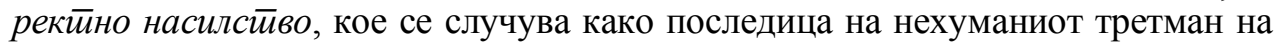
мајките? Дали бруталниот (немилосрден) однос спрема работниците бил воопто нужен и, ако бил, тогаш во која мера? Одговорот на последново прашање е важен, затоа што нужното насилство повлекува доза на оправданост, целисходност својствена за секое втемелувачко насилство (во име на некое општо добро или виша цел, па оттаму и се дефинира - парадоксално - како злояобро), додека ненужното е лишено од виша смисла и интерес за општонародното добро, оттаму е апсурдно, антицивилизациско, варварско, подложно на осуда (некогаш и во форма на кривично дело), така што не застарува (тука спаѓа и т.н. злосторство против човештвото).

Овој ист мотив е опеан и во Преяание за Прилей, Варош и околинайа и за бег̄ањетио на Марка Кралет̄а оя Варош, објавено под број 600, од истиот том број седум (Цепенков 1980: 122-127). За Калето се вели дека, за да го изгради, Марко „наредил чоек до чоек од калето та дури до Кукул, да подаваат камење од рака на рака. Кое бабата што (ги) лулала децата, го проколнала, кое жените дојарките - и го втасале клетвите сиромашки, та калето се запусти.“"(Цепенков 1980: 125-126). Меѓу жените имало мајки доилки и мајки со мали деца. Стотици бебиња и деца плачеле гладни, жедни, сами. Марко им забранил на мајките да си ги надгледуваат децата. Тој дозволил само една стара баба да се грижи за сите деца. Се разбира, таа стара жена не успевала да ги нахрани ниту да ги згрижи сите деца, па тие умирале. Не е познат бројот на децата жртвувани при sидањето на Кулите. Тоа жртвување содржи елементи на масовно и на прекумерно насилство. Сликата на стотиците деца што плачат по падините на планината над Прилеп е апокалиптична. Се верува, имено, дека Марковото Кале се запустило (како, впрочем, и црквите што Крале Марко ги градел во Прилеп и Варош), ${ }^{4}$ токму поради клетвите на угнетениот и онеправдан народ.

Колку што е прекумерноста на жртвувањето поголема толку е пологична идејата дека sидањето на Кулите можело да помине со помалку жртви. Значи, парадоксално, ама идејата за големите подвизи со коишто некој човек/владетел ја задолжува историјата како да имплицира некој поднослив минимум насилно жртвување. Прашањето не е дали треба да има жртви, туку дали може бројот на жртвите и нивното страдање да се сведе на некој поднослив минимум. Во ова предание се воведува и мотивот на анатемата, која дошла како „виша правда“" за измачениот народ и како казна за Крале Марко.

Крале Марко е митско-историска фигура на јунак и моќник, едновремено, јунак што е спасител на народот, но и моќник кој жртвува стотици деца за да

\footnotetext{
${ }^{4}$ Од 77 цркви зачувани се само неколку.
} 
изгради величествени зданија какви што се Калето и Кулата над Прилеп. Цената на неговите дела и зданија направени во име на општото добро не се пресметува само со бројот на експлицитните жртви туку и со геометриската прогресија на индиректно нанесените неправди: од уништување семејства до одземање на слободата на луѓето и непочитување на нивните елементарни права.

Поради тоа, Крале Марко има двоен карактер. Тој е првенствено мемориран во колективната свест и во преданието како народен, легендарен јунак, но на маргините на колективната меморија се испишани и некои траги на неговото антијунаштво, главно како последица на неекономичноста на жртвите. Таа неекономичност на жртвувањето го претвора ритуалот во насилство, всушност, го деритуализира чинот на жртвувањето и го претвора во прекумерно насилство. Колку и да се поставени на маргините на народното предание, потиснати во колективното несвесно, неправдите што им ги има нанесено Крале Марко на невините жртви се запаметени. Доволно за да бидат предмет на една културна херменевтика на насилството во сите негови видови, ритуални и прагматични.

\section{3 Економија на насилството}

Од наведениве примери е јасно дека македонските историски искуства го сугерираат сознанието дека за остварување на некои виши цели (општо добро) се неопходни жртви, а зад жртвите се крие некое насилство, некоја нанесена неправда, некое зло, некое отсуство на свест за општо добро. Кога насилството/неправдата е нанесена во форма на ритуална жртва, тоа значи дека на тој чин му претходи некоја традиција, некоја свест за смислата на насилството и за неговата оправданост и покритие.

Поради тоа, ритуалот подразбира „извесна економија на насилството“(Girard 2002: 469). Имено, категоријата економичност на жртвувањето и на насилството ја повлекува разликата меѓу т.н. мало и големо, оправдано и неоправдано, односно нужно и ненужно насилство. Ако големите зданија се симбол на цивилизацискиот напредок, а големите дела синоним за култура, тогаш може да се каже дека во темелите на секоја (нова) цивилизација и култура е положена некоја човечка жртва. Жртвата е предуслов за опстанок на заедницата и на вишиот интерес на заедницата.

Македонските народни преданија, сфатени како рефлектирано историско искуство, ја сугерираат идејата за „економичноста““ на ритуалот на жртвувањето. Тие ја покажуваат антиномичноста на некои егзистенцијални ситуации, кои го поставуваат прашањето на принудата и приоритетите: да се жртвува еден човек или да се жртвува целата заедница (народ, град, држава)? Од нив може да се изведе класификација на типовите насилно жртвување, затоа што во македонската култура се вкрстува локалното искуство со универзалното, односно историската свест со митската. 


\section{Библиографија}

Вражиновски, Т. (1983). Макеgонски нарояни ирреяанија. Скопје: Институт за фолклор „Марко Цепенков“".

Конески, Б. (2010). Поезија. Скопје: МАНУ.

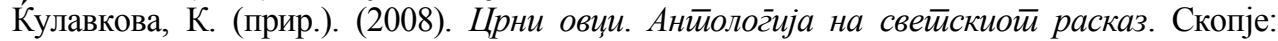
Детска радост/Просветно дело.

Куулавкова, К. (2009). Насилството и цивилизацијата. Во К.Ќулавкова. Демоноӣ на йолкувањейо, 21-52. Скопје: МАНУ.

Цепенков, М. (1980). Преданија. Во К. Пенушлиски (ред.). Макеоонски нарояни

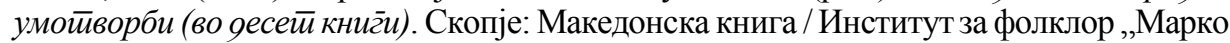
Цепенков“.

Girard, R. (2002). La violence et le sacré. Paris: Hachette. [Online] Available from: https://www.les-crises.fr/wp-content/uploads/2015/02/le-bouc-emissaire.pdf [Accessed: August 15th, 2019]

Sophie's Choice. (1982). Directed by Alan J. Pakula. [DVD].

Styron, W. (2010). Sophie's Choice. New York: Open Road Media. [Online] Available from: https://www.worldcat.org/title/sophies-choice/oclc/712026142 ISBN 1936317176 [Accessed: August 15th, 2019]

Yourcenar, M. (2016). Nouvelles orientales. Paris: Gallimard. [Online] Available from: http://excerpts.numilog.com/books/9782072698279.pdf [Accessed: August 15th, 2019] 